\title{
DIDACTICS: PECULIARITIES OF PROGRAMMED TEACHING OF A CARTWHEEL TO BOYS AGED 14
}

\author{
Alyona Suprun $^{1 \mathrm{ABCD}}$, Olha Ivashchenko ${ }^{1 \mathrm{ABCD}}$, Mirosława Cieślicka ${ }^{2 \mathrm{ACD}}$ \\ ${ }^{1}$ H. S. Skovoroda Kharkiv National Pedagogical University \\ ${ }^{2}$ Collegium Medicum: Bydgoszcz, Kujawsko Pomorskie \\ Authors' Contribution: A - Study design; B - Data collection; C - Statistical analysis; D - Manuscript Preparation; E - Funds Collection
}

DOI: $10.17309 / \mathrm{jltm} .2021 .3 .04$

\begin{abstract}
The purpose of the study was to determine the peculiarities of programmed teaching of a cartwheel to boys aged 14 . Material and methods. The study participants were 20 boys aged 14 . The children and their parents were fully informed about all the features of the study and gave their consent to participate in the experiment. To solve the tasks set, the following research methods were used: study and analysis of scientific and methodological literature; pedagogical observation, timing of training tasks; pedagogical experiment, methods of mathematical statistics, factor analysis.

Results. The analysis of similarities revealed that the program components are interrelated. Series of training tasks I, II and IV are combined into one group and provide conditions for teaching boys aged 14 a cartwheel.

Conclusions. As a result of factor analysis, the study obtained a two-factor model of the teaching program where training tasks are closely connected with one another, which indicates their effective selection. Factor models of the teaching program explain $69.371 \%$ and $75.394 \%$ of the variation of results. The study found that the effectiveness of the program depends on the modes of exercise repetition. The use of the mode of exercise repetition of 6 sets 2 times each with a rest interval of $60 \mathrm{~s}$ increases the effectiveness of the proposed program $(\mathrm{p}<0.05)$.
\end{abstract}

Keywords: programmed teaching, acrobatic exercises, boys.

\section{Introduction}

Programmed instruction was developed in the 1970s (Maehr, 1964; Newton \& Hickey, 1965; Woodruff, Faltz, \& Wagner, 1966). The aspects of programmed and traditional teaching were studied (Hughes, 1975). The prospects for modern development are associated with the latest technologies (Coughlan \& Coghlan, 2021; Johnson, Iversen, Kenyon, Holth, \& de Souza, 2020).

Studies by Shlemin (1973), Khudolii, Iermakov, \& Bartik (2020), Khudolii, \& Iermakov (2011) focus on the problem of programmed teaching in physical education. The researchers found the effectiveness of using the method of algorithmic instructions when teaching school program exercises (Ivashchenko, 2014, 2001; Khudolii, 2008; Khudolii, Iermakov, \& Bartik, 2020) and programming the development of strength in schoolchildren (Khudolii, Ivashchenko, \& Titarenko, 2013).

The method of algorithmic instructions gives the possibility to formulate subtasks within the holistic system of motor skills development. Thus, Khudolii and Iermakov (2011) point out that the level of strength development, muscle sensitivity

(C) Suprun, A., Ivashchenko, O., \& Cieślicka, M., 2021. and a training mode significantly influence the process of teaching motor actions. This fact makes it possible to formulate the following tasks of learning and training: 1) to develop motor abilities necessary for learning movements; 2) to teach the ability to control movements; 3 ) to ensure a high level of performance. Studies of the movement biomechanical structure allow us to formulate the following learning objectives: 1) to teach actions without which it is impossible to perform the exercise; 2) to teach preliminary exercises (Haverdovsky, 2003, 2007).

The selection of training tasks within the method of algorithmic instructions is based on the data about movement control in the process of skills development (Shlemin, 1973; Buckolz, Renger, Salmoni, Hall, \& Paunonen, 1990; Féry \& Morizot, 2000), about the need to control movements (Karabourniotis, Evaggelinou, Tzetzis, \& Kourtessis, 2002; Lakota, Talović, Jelešković, \& Bonacin, 2008; Park \& Buchanan, 2018) and the impact of visual information on the effectiveness of teaching (Smyth, 1978; Robertson, Germain, \& Ste-Marie, 2018; Khudolii, Iermakov, \& Bartik (2020).

Therefore, the study of the peculiarities of programmed teaching of physical exercises is relevant.

The purpose of the study was to determine the peculiarities of programmed teaching of a cartwheel to boys aged 14 . 


\section{Material and methods}

\section{Study participants}

The study participants were 20 boys aged 14 . The children and their parents were fully informed about all the features of the study and gave their consent to participate in the experiment.

\section{Organization of the study}

To solve the tasks set, the following research methods were used: study and analysis of scientific and methodological literature; pedagogical observation, timing of training tasks; pedagogical experiment, methods of mathematical statistics, factor analysis.

The pedagogical experiment examined the influence of 6 and 12 repetitions with a 60 -second rest interval during a physical education class on the number of repetitions of training tasks to the $100 \%$ level of proficiency. In the first group $(\mathrm{n}=10)$, the boys repeated the tasks 6 sets 1 time each with a rest interval of $60 \mathrm{~s}$, in the second group $(\mathrm{n}=10)-$ 6 sets 2 times each with a rest interval of $60 \mathrm{~s}$.
During teaching, the method of algorithmic instructions was used (Shlemin, 1973). The program of teaching the cartwheel included the training tasks given in Table 1. It was developed based on the data of Shlemin (1973), Khudolii (2008). The next exercise started on condition of correct performance of the previous exercise on three consecutive attempts. The number of repetitions required for correct performance on three consecutive attempts was recorded.

\section{Statistical analysis}

The study materials were processed using the IBM SPSS 20 statistical analysis program. Factor analysis was conducted.

The study protocol was approved by the Ethical Committee of the University. In addition, the children and their parents or legal guardians were fully informed about all the features of the study, and a signed informed consent document was obtained from all the parents.

\section{Results}

Table 1 shows the results of a comparative analysis of the effectiveness of the program of teaching boys aged 14 the

Table 1. Program of teaching the cartwheel (Shlemin, 1973; Khudolii, 2008)

\begin{tabular}{ccc}
\hline $\begin{array}{c}\text { Informative frame } \\
\text { (what is performed) }\end{array}$ & $\begin{array}{c}\text { Operational frame } \\
\text { (how it is performed) }\end{array}$ & $\begin{array}{c}\text { Control frame } \\
\text { (proceed to training the next } \\
\text { exercise) }\end{array}$ \\
\hline
\end{tabular}

The first series of training tasks - exercises to develop motor abilities

From normal standing position, lean forward, touch When performing the exercise, do not

the floor with the hands and, moving the hands forward on the floor, adopt a push-up position, return to starting position in the same way

Perform push-ups as quickly as possible (5 times in 3-4s)
If the student performs the maximal number in 10 seconds, proceed to the next exercise

Perform the exercise as quickly as possible, If the student performs the maintaining a gymnastic style exercise in 3-4 seconds, proceed to the next exercise

The second series of training tasks - exercises to master starting and ending positions

From standing position with raised arms, step forward Switch leg handstand and perform a switch leg handstand with assistance

Handstand with legs apart with assistance
Correct performance in a series of 3 attempts

Switch leg handstand, maintaining balance Correct performance in a series of for 3-4 seconds

The third series of training tasks - actions without which it is impossible to perform the target exercise

Standing on hands with legs apart with assistance, Perform everything only with assistance Correct performance in a series of shift the body weight from one hand to the other 3 attempts

The fourth series of training tasks - teaching the ability to assess movements in space, by time and muscular effort

Arriving to handstand quickly with assistance

Arriving to handstand slowly with assistance
Correct performance in a series of 3 attempts

Correct performance in a series of 3 attempts

Pay attention to the technique of performance

Pay attention to the technique of performance

\section{The fifth series of training tasks - preliminary exercises}

Arriving to handstand quickly with the wall support Maintain balance for 3-4 seconds

Handstand with legs apart with 90-degree rotation with assistance

Cartwheel with assistance

Cartwheel without assistance
Perform all exercises for this element only with assistance
Correct performance in a series of 3 attempts

Correct performance in a series of 3 attempts
The sixth series of training tasks - the entire exercise

Pay attention to the technique of performance

Maintain a gymnastic style
Correct performance in a series of 3 attempts

Correct performance in a series of 3 attempts 
Table 1. Analysis of the effectiveness of the program of teaching boys aged 14 the cartwheel using different repetition modes

\begin{tabular}{|c|c|c|c|c|c|c|c|c|c|c|}
\hline & \multirow{3}{*}{ mode } & \multirow{3}{*}{$\mathbf{n}$} & \multirow{3}{*}{$\mathbf{M}$} & \multirow{3}{*}{ SD } & \multicolumn{6}{|c|}{ t-test for Equality of Means } \\
\hline & & & & & \multirow[t]{2}{*}{$\mathbf{t}$} & \multirow{2}{*}{$\mathbf{p}$} & \multirow[t]{2}{*}{ MD } & \multirow[t]{2}{*}{ SED } & \multicolumn{2}{|c|}{$\begin{array}{l}\text { 95\% Confidence Interval of the } \\
\text { Difference }\end{array}$} \\
\hline & & & & & & & & & Lower & Upper \\
\hline \multirow{2}{*}{$\begin{array}{l}\text { Total number of } \\
\text { repetitions }\end{array}$} & 1 & 10 & 52.3 & 7.13 & \multirow{2}{*}{2.096} & \multirow{2}{*}{0.05} & \multirow{2}{*}{7.9} & \multirow{2}{*}{3.776} & \multirow{2}{*}{-.02} & \multirow{2}{*}{15.82} \\
\hline & 2 & 10 & 44.4 & 9.54 & & & & & & \\
\hline
\end{tabular}

1 - mode of 6 sets 1 time each with a rest interval of $60 \mathrm{~s} ; 2$ - mode of 6 sets 2 times each with a rest interval of $60 \mathrm{~s}$ )

cartwheel using different repetition modes. It was found that the mode of 6 sets 2 times each with a rest interval of $60 \mathrm{~s}$ is more effective $(\mathrm{p}<0.05)$.

Structural analysis of the program of teaching boys aged 14 the cartwheel (mode of 6 sets 1 time each with a rest interval of $60 \mathrm{~s}$ )

As a result of factor analysis, two factors that explain $69.371 \%$ of the variation of results were identified. The first factor explains $47.742 \%$ of the variation of learning out-

Table 2. Results of factor analysis of the teaching program (6 repetitions, rest interval of $60 \mathrm{~s}$ ). Rotated Component Matrix

\begin{tabular}{|c|c|c|c|}
\hline \multirow{2}{*}{ Series of training tasks } & \multicolumn{2}{|c|}{ Component } & \multirow{2}{*}{$\mathbf{h}^{2}$} \\
\hline & 1 & 2 & \\
\hline Series 1 & .895 & .355 & .926 \\
\hline Series 2 & 652 & .172 & .455 \\
\hline Series 3 & .685 & -.387 & 619 \\
\hline Series 4 & .776 & .146 & .624 \\
\hline Series 5 & & .851 & .727 \\
\hline Series 6 & .395 & .606 & .524 \\
\hline Total number of repetitions & .941 & .309 & .981 \\
\hline
\end{tabular}

Table 3. Total Variance Explained

\begin{tabular}{ccc}
\hline \multirow{2}{*}{ Component } & \multicolumn{2}{c}{ Rotation Sums of Squared Loadings } \\
\cline { 2 - 3 } & \% of Variance & Cumulative \% \\
\hline 1 & 47.742 & 47.742 \\
2 & 21.630 & 69.371 \\
\hline
\end{tabular}

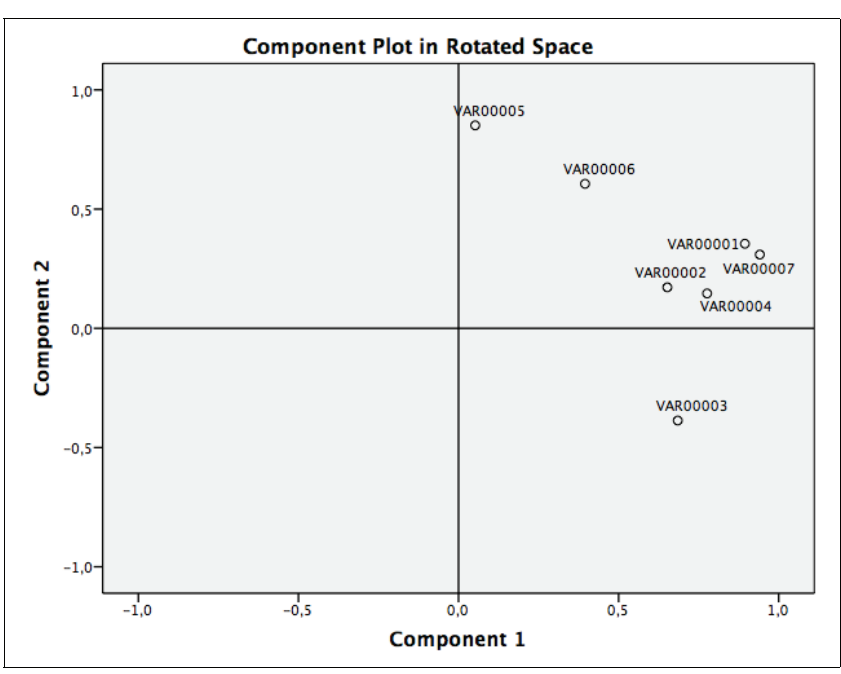

Fig. 1. Results of factor analysis of the teaching program (6 repetitions, rest interval of $60 \mathrm{~s}$ ) comes. The series that are most correlated with the factor are: I - exercises to develop motor abilities $(r=0.895)$; IV - teaching the ability to assess movements in space, by time and muscular effort $(\mathrm{r}=0.776)$; III - actions without which it is impossible to perform the target exercise $(r=0.685)$; II exercises to master starting and ending positions $(r=0.652)$.

The second factor explains $21.630 \%$ of the variation of learning outcomes. The series that are most correlated with the factor are: $\mathrm{V}$ - preliminary exercises $(\mathrm{r}=0.851)$; VI - the entire exercise $(r=0.606)$.

The analysis of similarities revealed that all the program components are interrelated (Table 2). Series of training tasks I, II and IV are combined into one group and provide conditions for teaching boys aged 14 the cartwheel (Fig. 1).

Structural analysis of the program of teaching boys aged 14 the cartwheel (mode of 6 sets 2 times each with a rest interval of $60 \mathrm{~s}$ )

As a result of factor analysis, two factors that explain $75.394 \%$ of the variation of results were identified (Tables 4 , 5). The first factor explains $46.688 \%$ of the variation of learning outcomes. The series that are most correlated with the factor are: I - exercises to develop motor abilities $(r=0.845)$; III - actions without which it is impossible to perform the target exercise $(\mathrm{r}=0.958) ; \mathrm{V}$ - preliminary exercises $(\mathrm{r}=$ 0.754).

The second factor explains $28.705 \%$ of the variation of learning outcomes. The series that are most correlated with the factor are: VI - the entire exercise $(r=0.779)$; IV - teaching the ability to assess movements in space, by time and

Table 4. Results of factor analysis of the teaching program (12 repetitions, rest interval of $60 \mathrm{~s}$ ). Rotated Component Matrix

\begin{tabular}{lccc}
\hline \multirow{2}{*}{ Series of training tasks } & \multicolumn{2}{c}{ Component } & \multirow{2}{*}{$\mathbf{h}^{2}$} \\
\cline { 2 - 3 } & $\mathbf{1}$ & $\mathbf{2}$ & \\
\hline Series 1 & .845 & .281 & .794 \\
Series 2 & -.264 & .634 & .472 \\
Series 3 & .958 & .147 & .940 \\
Series 4 & .577 & .688 & .807 \\
Series 5 & .754 & -.188 & .604 \\
Series 6 & .274 & .779 & .681 \\
Total number of repetitions & .767 & .625 & .980 \\
\hline
\end{tabular}

Table 5. Total Variance Explained

\begin{tabular}{ccc}
\hline \multirow{2}{*}{ Component } & \multicolumn{2}{c}{ Rotation Sums of Squared Loadings } \\
\cline { 2 - 3 } & \% of Variance & Cumulative \% \\
\hline 1 & 46.688 & 46.688 \\
2 & 28.705 & 75.394 \\
\hline
\end{tabular}


muscular effort $(\mathrm{r}=0.688)$; II - exercises to master starting and ending positions $(\mathrm{r}=0.634)$.

The analysis of similarities revealed that all the program components are interrelated (Table 4). Series of training tasks I and II are combined into one group and indicate that in the process of teaching boys aged 14 the cartwheel, these two series of training tasks can be studied in parallel (Fig. 2).

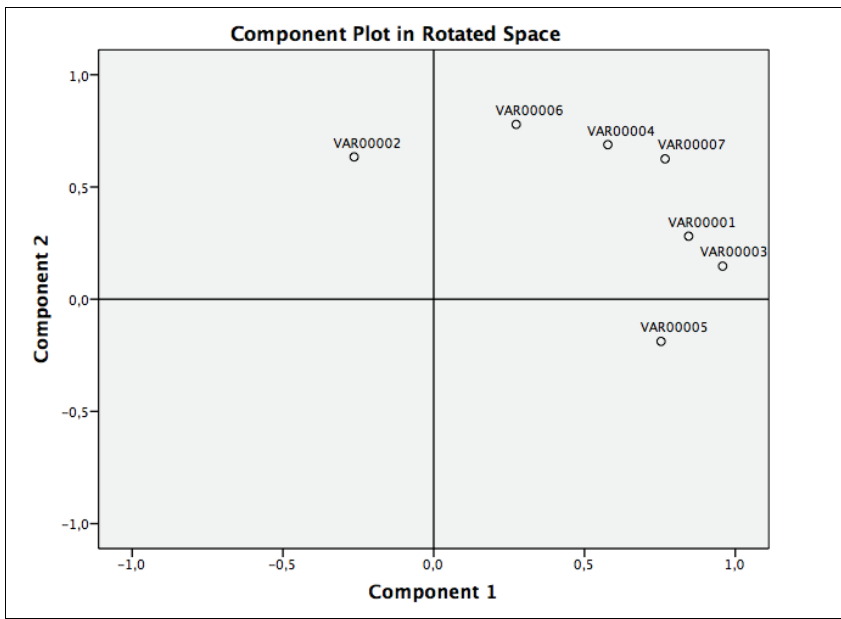

Fig. 2. Results of factor analysis of the teaching program (12 repetitions, rest interval of $60 \mathrm{~s}$ )

The analysis of implementation of the teaching program under the conditions of two exercise modes using the Nearest Neighbor Analysis showed that the tasks of series 1, 2 and 3 are most interrelated with one another (Table 6, Fig. 3).

Table 6. Nearest Neighbor Analysis

\begin{tabular}{llrr}
\hline \multicolumn{3}{c}{ Case Processing Summary } \\
\hline \multicolumn{3}{c}{$\mathbf{N}$} & Percent \\
\hline \multirow{2}{*}{ Sample } & Training & 17 & $85.0 \%$ \\
& Holdout & 3 & $15.0 \%$ \\
Valid & & 20 & $100.0 \%$ \\
Excluded & & 0 & \\
Total & & 20 & \\
\hline
\end{tabular}

\section{Discussion}

As a result of the pedagogical experiment, the peculiarities of programmed teaching of the cartwheel to boys aged 14 were determined. The study obtained factor models of the teaching program which explain $69.371 \%$ and $75.394 \%$ of the variation of results. As a result of factor analysis, the study obtained a two-factor model of the teaching program where training tasks are closely connected with one another, which indicates their effective selection. It was found that the use of the mode of exercise repetition of 6 sets 2 times each with a rest interval of $60 \mathrm{~s}$ increases the effectiveness of the proposed program $(\mathrm{p}<0.05)$.

The obtained data supplement the results of the study on the patterns of motor skills development (Kapkan, Khudolii, \& Bartik, P2019; Ivashchenko, 2020; Khudolii, Iermakov, \& Bartik, 2020) and indicate that the effectiveness of the program can vary depending on exercise repetition modes.

The data presented confirm the effectiveness of the method of algorithmic instructions for motor skills development in children and adolescents (Shlemin, 1973; Khudolii, Iermakov, \& Bartik, 2020; Ivashchenko, 2020). Factor analysis revealed that series of training tasks IV (the ability to assess the performance of movements in space, by time and muscular effort) is essential in motor skill development. This confirms the data of researchers about the need to focus on movement control (Buckolz, Renger, Salmoni, Hall, \& Paunonen, 1990; Féry, \& Morizot, 2000; Ashford, Bennett, \& Davids, 2006), on the control of exercise performance (Karabourniotis, Evaggelinou, Tzetzis, \& Kourtessis, 2002; Lakota, Talović, Jelešković, \& Bonacin, 2008; Park, \& Buchanan, 2018), and on the effectiveness of visual information in the process of motor skills development (Smyth, 1978; Robertson, Germain, \& Ste-Marie, 2018).

\section{Conclusions}

As a result of factor analysis, the study obtained a twofactor model of the teaching program where training tasks are closely connected with one another, which indicates their effective selection. Factor models of the teaching program ex-

\section{Predictor Space}

Built Model: 3 selected predictors, $K=3$

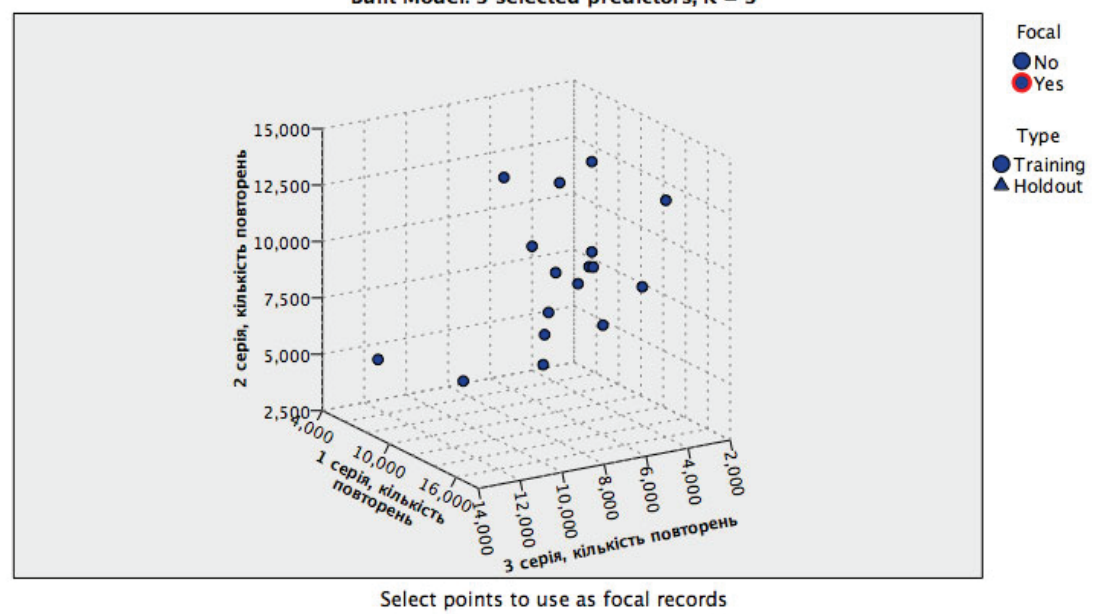

This chart is a lower-dimensional projection of the predictor space, which contains a total of 7 predictors.

Fig. 3. Nearest Neighbor Analysis 
plain $69.371 \%$ and $75.394 \%$ of the variation of results. Series of training tasks IV (the ability to assess the performance of movements in space, by time and muscular effort) is essential in motor skill development. The study found that the effectiveness of the program depends on the modes of exercise repetition. The use of the mode of exercise repetition of 6 sets 2 times each with a rest interval of $60 \mathrm{~s}$ increases the effectiveness of the proposed program $(\mathrm{p}<0.05)$.

\section{Acknowledgment}

The study was carried out according to the research plan of the Department of Theory and Methodology of Physical Education of H. S. Skovoroda Kharkiv National Pedagogical University within the topic "Theoretical and methodological foundations of modeling the learning process and motor abilities development in children and adolescents" (20132022) (state registration number 0112U002008).

\section{Conflict of interest}

The authors declare that there is no conflict of interest.

\section{References}

Maehr, M. L. (1964). Programed learning and the role of the teacher. Journal of Educational Research, 57(10), 554-556. Scopus. https://doi.org/10.1080/00220671.1964.10883149

Newton, J. M., \& Hickey, A. E. (1965). Sequence effects in programed learning of a verbal concept. Journal of Educational Psychology, 56(3), 140-147. Scopus. https://doi.org/10.1037/h0022020

Woodruff, A. B., Faltz, C., \& Wagner, D. (1966). Effects of learner characteristics on programed learning performance. Psychology in the Schools, 3(1), 72-77. Scopus. https://doi.org/10.1002/15206807(196601)3:1<72::AID-PITS2310030120>3.0.CO;2-P

Hughes, D. C. (1975). Programmed Learning and Conventional Teaching. Educational Research, 18(1), 54-61. Scopus. https://doi.org/10.1080/0013188750180107

Coughlan, P., \& Coghlan, D. (2021). What happens to P? Lessons from network action learning research. Action Learning: Research and Practice, 18(2), 91-101. Scopus. https://doi.org/10.1080/14767333.2021.1884044

Johnson, C., Iversen, I., Kenyon, P., Holth, P., \& de Souza, D. G. (2020). Murray Sidman: A life of giving. Journal of Applied Behavior Analysis, 53(3), 1290-1298. Scopus. https://doi.org/10.1002/jaba.718

Shlemin, A.M. (1973). Iunyi gimnast. M.: Fizkultura i sport, 376. Kapkan, O., Khudolii, O., \& Bartik, P. (2019). Motor Skills Development: Optimization of Teaching Boys Aged 14. Teoriâ ta Metodika Fizičnogo Vihovannâ, 19(3), 148155. https://doi.org/10.17309/tmfv.2019.3.06

Khudolii, O., \& Iermakov, S. (2011). Zakonomirnosti protsesu navchannia yunykh himnastiv.Teoriâ ta Metodika Fizičnogo Vihovannâ, (5), 3-18, 35. https://doi.org/10.17309/tmfv.2011.5.707

Ivashchenko, O. (2001). Metodyka navchannia himnastychnykh vprav shkilnoi prohramy. Teoriia ta metodyka fizychnoho vykhovannia, (1), 26-31. https://doi.org/10.17309/tmfv.2001.1.7
Khudolii, O.M. (2008). Osnovy metodyky vykladannia himnastyky: Navch. posibnyk. U 2-kh tomakh. 4-e vyd., vypr. i dop. Kharkiv: «OVS», T. 1, 408.

Ivashchenko, V. (2014). Osnovy teorii ta metodyky prohramovanoho navchannia rukhovym diiam. Teoriâ ta Metodika Fizičnogo Vihovannâ, (3), 29-33. https://tmfv.com.ua/journal/article/view/133

Khudolii, O., Iermakov, S., \& Bartik, P. (2020). Didactics: Methodological Basis of Motor Learning in Children and Adolescents. Journal of Learning Theory and Methodology, 1(1), 5-13. https://doi.org/10.17309/jltm.2020.1.01

Khudolii, O., Ivashchenko, O., \& Titarenko, A. (2013). Osoblyvosti prohramuvannia rozvytku syly u khlopchykiv molodshykh klasiv. Teoriâ ta Metodika Fizičnogo Vihovannâ, (3), 3-12. https://doi.org/10.17309/tmfv.2013.3.1020

Kapkan, O., Khudolii, O., \& Bartik, P. (2019). Pattern Recognition: Motor Skills Development in Girls Aged 15. Teoriâ ta Metodika Fizičnogo Vihovannâ, 19(1), 44-52. https://doi.org/10.17309/tmfv.2019.1.06

Ivashchenko, O. (2020). Research Program: Modeling of Motor Abilities Development and Teaching of Schoolchildren. Teoriâ ta Metodika Fizičnogo Vihovannâ, 20(1), 32-41. https://doi.org/10.17309/tmfv.2020.1.05

Khudolii, O., \& Iermakov, S. (2011). Zakonomirnosti protsesu navchannia yunykh himnastiv. Teoriâ ta Metodika Fizičnogo Vihovannâ, (5), 3-18, 35. https://doi.org/10.17309/tmfv.2011.5.707

Gaverdovskii, Iu.K. (2003). O kauzalnoi strukture sportivnykh dvizhenii. Teoriia i praktika fiz. kultury, (2), 14-19.

Gaverdovskii, Iu.K. (2007). Obuchenie sportivnym uprazhneniiam. Biomekhanika. Metodologiia. Didaktika. M.: Fizkultura i sport, 912.

Buckolz, E., Renger, R., Salmoni, A., Hall, C., \& Paunonen, S. V. (1990). Error recognition ability and the retention of rapid timing movements. Human Movement Science, 9(1), 3-21. Scopus. https://doi.org/10.1016/0167-9457(90)90032-9

Féry, Y.-A., \& Morizot, P. (2000). Kinesthetic and visual image in modeling closed motor skills: The example of the tennis serve. Perceptual and Motor Skills, 90(3), 707-722. Scopus. https://doi.org/10.2466/pms.2000.90.3.707

Ashford, D., Bennett, S. J., \& Davids, K. (2006). Observational modeling effects for movement dynamics and movement outcome measures across differing task constraints: A meta-analysis. Journal of Motor Behavior, 38(3), 185-205. Scopus. https://doi.org/10.3200/JMBR.38.3.185-205

Karabourniotis, D., Evaggelinou, C., Tzetzis, G., \& Kourtessis, T. (2002). Curriculum enrichment with self-testing activities in development of fundamental movement skills of first-grade children in Greece. Perceptual and Motor Skills, 94(3 PART 2), 1259-1270. Scopus. https://doi.org/10.2466/pms.2002.94.3c.1259

Lakota, R., Talović, M., Jelešković, E., \& Bonacin, D. (2008). The effects of the programmed training on the transformation of the qualitative level in the situationalmotor skills with handball players aged 11-14. Sport Science, 1(2), 60-64. Scopus.

Park, I., \& Buchanan, J. J. (2018). Motor Skill Learning and the Development of Visual Perception Processes Supporting 
Action Identification. Journal of Motor Behavior, 50(5), 566-578. Scopus.

https://doi.org/10.1080/00222895.2017.1378995

Smyth, M. M. (1978). Attention to visual feedback in motor learning. Journal of Motor Behavior, 10(3), 185-190.

Scopus. https://doi.org/10.1080/00222895.1978.10735152
Robertson, R., Germain, L. S., \& Ste-Marie, D. M. (2018). The effects of self-observation when combined with a skilled model on the learning of gymnastics skills. Journal of Motor Learning and Development, 6(1), 18-34. Scopus. https://doi.org/10.1123/jmld.2016-0027

\title{
ДИДАКТИКА: ОСОБЛИВОСТІ ПРОГРАМОВАНОГО НАВЧАННЯ ПЕРЕВОРОТУ УБІК ХЛОПЦІВ 14 РОКІВ
}

\author{
Альона Супрун ${ }^{1 A B C D}$, Ольга Іващенко ${ }^{1 A B C D}$, Мирослава Цислицька ${ }^{2 A C D}$ \\ ${ }^{1}$ Харківський національний педагогічний університет імені Г.С. Сковороди \\ ${ }^{2}$ Медичний колегіум: Бидгощ, Куявсько-Поморське воєводство \\ Авторський вклад: А - дизайн дослідження; В - збір даних; C - статаналіз; D - підготовка рукопису; Е - збір коштів \\ Реферат. Статья: 6 с., 6 табл., 3 рис., 27 джерел.
}

Мета дослідження - визначити особливості програмованого навчання перевороту убік хлопців 14 років.

Матеріал і методи. У дослідженні прийняли участь 20 хлопців 14 років. Діти та їхні батьки були інформовані про всі особливості дослідження і дали згоду на участь в експерименті. Для вирішення поставлених завдань були використані методи дослідження: вивчення та аналіз науково-методичної літератури; педагогічне спостереження, хронометраж навчальних завдань; педагогічний експеримент, методи математичної статистики, факторний аналіз.

Результати. Аналіз спільностей дозволив встановити, що компоненти програми взаємозв'язані. I, II та IV серії навчальних завдань об'єднуються в одну плеяду і забезпечують умови для навчання перевороту убік хлопців 14 років.
Висновки. У результаті факторного аналізу отримано двох факторну модель програми навчання у якій кожне навчальне завдання має тісний зв'язок між собою, що свідчить про їх ефективний підбір. Факторні моделі програми навчання на 69,371\% та 75,394\% пояснюють варіацію результатів. Встановлено, що ефективність програми залежить від режимів повторення вправ. Використання режиму повторення вправ 6 підходів по 2 рази з інтервалом відпочинку 60 с підвищує ефективність запропонованої програми $(\mathrm{p}<0,05)$.

Ключові слова: програмоване навчання, акробатичні вправи, хлопці.

\section{Information about the authors:}

Suprun Alyona: alyonasuprun1987@gmail.com; https://orcid.org/0000-0001-9885-284X; H. S. Skovoroda Kharkiv National Pedagogical University, Department of Theory and Methodology of Physical Education, Alchevskykh St, 29, Kharkiv, 61002, Ukraine.

Ivashchenko Olha: ivashchenko@hnpu.edu.ua; https://orcid.org/0000-0002-2708-5636; H. S. Skovoroda Kharkiv National Pedagogical University, Department of Theory and Methodology of Physical Education, Alchevskykh St, 29, Kharkiv, 61002, Ukraine.

Cieślicka Mirosława: cudaki@op.pl; https://orcid.org/0000-0002-0407-2592; Collegium Medicum: Bydgoszcz, Kujawsko Pomorskie, Chodkiewicza St, 30, 85-064 Bydgoszcz, Poland.

Cite this article as: Suprun, A., Ivashchenko, O., \& Cieślicka, M. (2021). Didactics: Peculiarities of Programmed Teaching of a Cartwheel to Boys Aged 14. Journal of Learning Theory and Methodology, 2(3), 128-133. https://doi.org/10.17309/jltm.2021.3.04

Received: 25.09.2021. Accepted: 05.10.2021. Published: 30.10.2021

This work is licensed under a Creative Commons Attribution 4.0 International License (http://creativecommons.org/licenses/by/4.0). 